\title{
Interakcija između predznaka i pariteta pri obradi jednoznamenkastih brojeva
}

\author{
Vanja Topić ${ }^{1}$, Mia Šetić Beg² i Dražen Domijan ${ }^{3}$ \\ ${ }^{1}$ Sveučilište u Mostaru, Filozofski fakultet, Mostar, Bosna i Hercegovina \\ ${ }^{2}$ Hrvatsko katoličko sveučilište, Odjel za psihologiju, Zagreb, Hrvatska \\ ${ }^{3}$ Sveučilište u Rijeci, Filozofski fakultet, Rijeka, Hrvatska
}

\begin{abstract}
Sažetak
Razumijevanje apstraktnih pojmova predstavlja važan izazov za teorijski okvir utemeljene kognicije. Jedna je mogućnost da se apstraktni pojmovi utemeljuju u afektivnim stanjima. U ovome smo radu ispitali hipotezu povezuje li se apstraktni matematički pojam parnosti broja (par - nepar) s pozitivnim i negativnim afektivnim tonom koji je indirektno naznačen predznakom plus i minus. U prvome su eksperimentu ispitanici odgovarali na pitanje je li prezentirani broj paran ili neparan. Kao podražaji prezentirani su cijeli brojevi u rasponu od -9 do 9 bez -5, 0 i 5. Rezultati su pokazali dvosmjernu interakciju između predznaka i parnosti jer su ispitanici bili efikasniji u obradi pozitivnih nego u obradi negativnih parnih brojeva. Također, bili su efikasniji u obradi negativnih nego u obradi pozitivnih neparnih brojeva. U drugome su eksperimentu ispitanici odgovarali na pitanje je li prezentirani broj numerički veći ili manji od 5, pri čemu su trebali ignorirati predznak. Prezentirani su isti podražaji kao i u prvome eksperimentu. Dobivena je složenija trosmjerna interakcija u kojoj su ispitanici bili efikasniji u obradi pozitivnih nego u obradi negativnih parnih brojeva, kao i u prvome eksperimentu, ali taj se efekt pojavio samo za brojeve veće od 5. Rezultati su interpretirani u okviru teorije o korespondenciji polariteta i teorije centralnoga afektivnog utemeljenja.
\end{abstract}

Ključne riječi: brojevi, parnost, razumijevanje apstraktnih pojmova, utjelovljena kognicija

\section{Uvod}

Teorije reprezentacije znanja pokušavaju odgovoriti na pitanje kako ljudi znaju tako mnogo iz tako malo informacija koje dobivaju. Jedna je varijanta toga problema

Dražen Domijan, Odsjek za psihologiju, Filozofski fakultet Sveučilišta u Rijeci, Sveučilišna avenija 4, 51000 Rijeka. E-pošta: drazen.domijan@uniri.hr

Rad je nastao u okviru projekata Kognitivni procesi u zadacima numeričkog $i$ taktičkog odlučivanja (HKS-2018-5) koji financira Hrvatsko katoličko sveučilište te projekta Neurodinamičko modeliranje vidne percepcije $i$ pažnje (uniri-drustv-18-177) koji financira Sveučilište u Rijeci. 
kako djeca usvajaju značenje mnoštva riječi kojima su izložena. Kao rješenje predloženi su modeli koji ekstrahiraju značenje riječi iz statističkih pravilnosti njihova zajedničkog pojavljivanja u tekstu. Prema hiperprostornoj analogiji jezika (engl. Hyperspace analogue to language, HAL) koju su predložili Burgess i Lund (1997) značenje riječi nastaje iz dimenzionalne analize različitih konteksta u kojima se riječ pojavljuje. U tome se modelu polazi od velikoga korpusa riječi i tekstova koji se analiziraju koristeći pomični prozor veličine 10 riječi. Kreira se velika dvodimenzionalna matrica s otprilike 70000 stupaca i redaka. Svaki redak i stupac označen je jednom riječju. Na taj način svaka lokacija u matrici sadrži kvantitativnu mjeru blizine dviju riječi unutar pokretnoga prozora. Prema latentnoj semantičkoj analizi (engl. latent semantic analysis, LSA) koju su predložili Landauer i Dumais (1997) značenje proizlazi iz statističke analize zajedničkoga pojavljivanja riječi. Kao i kod HAL-e, i kod LSA-e polazi se od matrične reprezentacije riječi, s razlikom da kod LSA-e svaki redak predstavlja jednu riječ, a svaki stupac predstavlja jedan tekst iz korpusa. Primjerice, ako se kao korpus tekstova uzme neka enciklopedija (Landauer i Dumais uzeli su američku akademsku enciklopediju Grolier s 30473 natuknice), tad je svaka natuknica u enciklopediji zaseban kontekst, odnosno stupac u matrici.

HAL i LSA motivirali su razvoj novih računalnih metoda ekstrahiranja znanja iz velikih korpusa tekstova koji pokazuju impresivne rezultate na zadacima koji ispituju semantiku (Hollis, 2017; Hollis i Westbury, 2016; Lenci, 2018; McNamara, 2011; Yee i sur., 2018). Međutim, ključni je nedostatak svih statističkih modela da ne mogu riješiti problem uzemljenja ili utemeljenja simbola (engl. symbol grounding) na koji su prvi upozorili Searle (1980) i Harnad (1990). Problem se sastoji u tome da simbolička reprezentacija znanja ne daje odgovor na pitanje kako su simboli povezani s vanjskim svijetom, odnosno s objektima koje označavaju. Problem se može prikazati misaonim eksperimentom u kojemu čovjek dolazi na aerodrom u nekoj stranoj zemlji jezik koje ne razumije (npr. kineski). Da bi se snašao i protumačio simbole na natpisima, čovjek kupuje rječnik, ali u tome su rječniku svi simboli objašnjeni drugim simbolima iz istoga jezika. Dakle, da bi shvatio značenje simbola na natpisima, čovjek mora odgonetnuti značenje prvoga simbola u rječniku koji objašnjava traženi simbol. Međutim, budući da čovjek ne razumije ni taj prvi simbol, mora u rječniku potražiti njegovo značenje, ali i on je definiran nekim drugim nerazumljivim simbolima, i tako se čovjek vrti u krug i nikako ne uspijeva dokučiti značenje simbola na natpisima. Drugim riječima, reprezentacija znanja koja se sastoji samo od relacija među simbolima ne može u potpunosti zahvatiti značenje pojmova jer joj nedostaje kontakt s referentnim objektima, odnosno nedostaje joj utemeljenje u okolini.

Rješenje za problem utemeljenja simbola predložila je teorija sustava perceptivnih simbola koja pretpostavlja postojanje direktne veze između pojma i perceptivnih, motoričkih i afektivnih iskustava povezanih s objektom koji pojam označava (Barsalou, 1999, 2003). Veza je između pojma i percepcije obostrana, tako 
da percipiranje objekta omogućuje i njegovo imenovanje i dohvaćanje svih drugih aspekata pojmovnoga znanja o tome objektu, ali i obratno, svaki put kad čujemo za neki pojam ili razmišljamo o njemu djelomično se reaktiviraju perceptivna iskustva objekta koji taj pojam označava. Ta iskustva nisu savršena ni detaljna, ali dovoljna su da nam omoguće razumijevanje pojma. Takvo pojmom izazvano reaktiviranje perceptivnih i motoričkih iskustava naziva se perceptivnom simulacijom. Simulacija nije isto što i sama percepcija ili motorika jer uključuje određeni stupanj apstrahiranja, odnosno shematizacije kojom se isključuju nebitni detalji i zadržavaju samo ključna obilježja označenoga objekta. Slične ideje izložene su i u indeksnoj hipotezi (Glenberg i Robertson, 1999; Kaschak i Glenberg, 2000) i modelu prožetoga iskustvenika (Zwaan, 2004). Svi se ti modeli mogu podvesti pod zajednički teorijski okvir koji se naziva utemeljena kognicija (engl. grounded cognition) ili utjelovljena kognicija (engl. embodied cognition) koji je izrastao u zaseban istraživački program u kognitivnoj znanosti (Barsalou, 2008, 2020; Coello i Fischer, 2016; Fischer i Coello, 2016; Shapiro, 2019; Varela i sur., 2017).

Osnovna je pretpostavka utemeljene kognicije da obilježja senzorno-motoričkih sustava utječu na razumijevanje pojmova, kao što i pojmovna obrada utječe na percepciju i motoriku. Ta je pretpostavka ispitivana u mnoštvu studija u kojima je otkrivena interakcija između percepcije i motorike i brzine pojmovne obrade. Na primjer, otkriveno je da se perceptivna simulacija spontano aktivira tijekom obrade rečenice i kreira mentalni model situacije opisane u rečenici. Kreirani model zatim ubrzava rješavanje zadatka ako rečenicu prati slika koja odgovara modelu (Stanfield i Zwaan, 2001; Zwaan i Pecher, 2012; Zwaan i sur., 2002). Nadalje, neuroznanstvena istraživanja korištenjem tehnika oslikavanja mozga pokazala su djelomično preklapanje neuronske aktivnosti koja se pojavljuje kod pojmovne obrade i kod percepcije i motorike (Martin, 2016). Međutim, ostalo je neriješeno pitanje kako utemeljena kognicija može reprezentirati apstraktne pojmove kao što su pravda, jedinstvo ili znanje koji označavaju pojave i entitete s kojima nemamo direktna perceptivna ili motorička iskustva koja mogu poslužiti za njihovo utemeljenje (Borghi, 2020; Borghi i sur., 2017; Dove, 2016; Ostarek i Huettig, 2019). Predložena su dva rješenja toga problema: jedno se zasniva na teoriji o pojmovnim metaforama (Lakoff i Johnson, 1980, 1999), a drugo na afektivnome utemeljenju (Kousta i sur., 2011; Vigliocco i sur., 2014).

Lakoff i Johnson (1980) analizom upotrebe metafora u svakodnevnoj komunikaciji došli su do zaključka da metafora nije samo poetsko sredstvo karakteristično za književnost nego temeljni kognitivni mehanizam putem kojega se ostvaruje preslikavanje između izvorne (konkretne) domene i ciljne (apstraktne) domene. Izvorna je domena utemeljena u konkretnome iskustvu interakcije s okolinom i sastoji se od maloga skupa pojmova koji označavaju prostorne odnose (gore - dolje, naprijed - natrag, blizu - daleko), fizičke ontološke pojave (entitet, spremnik) i osnovne doživljaje i radnje (kretanje, hranjenje). Ti pojmovi ne zahtijevaju daljnju elaboraciju unutar pojmovnoga sustava, već su razumljivi sami 
po sebi. Ciljnu domenu sačinjava struktura obilježja nekoga apstraktnog pojma za koju pronalazimo sličnosti s izvornom domenom. Preslikavanje se ostvaruje putem pojmovne metafore koja sustavno povezuje dvije domene.

Drugi pristup utemeljenju apstraktnih pojmova ukazuje na važnu ulogu emocija. Prema teoriji afektivnoga utemeljenja apstraktni su pojmovi utemeljeni u afektivnim iskustvima i emocionalnome razvoju (Kousta i sur., 2011; Vigliocco i sur., 2013). Drugim riječima, emocionalni razvoj predstavlja osnovu za usvajanje apstraktnoga rječnika. Potvrde su za tu teoriju nalazi iz razvojne psihologije koji pokazuju da se emocionalne apstraktne riječi usvajaju prije afektivno neutralnih apstraktnih riječi. Apstraktne riječi izazivaju više emocionalnih asocijacija od konkretnih riječi. Kad se u zadatku leksičke odluke kontroliraju svi drugi relevantni faktori kao što su poznatost, predočivost, dostupnost konteksta, dob usvajanja i način usvajanja riječi (perceptivno ili lingvistički), pojavljuje se efekt apstraktnosti, odnosno ispitanici brže reagiraju na apstraktne riječi nego na konkretne (Kousta i sur., 2011). Taj je efekt dobiven na velikome uzorku od 2330 testiranih riječi. Nadalje, tehnikama oslikavanja mozga pokazalo se da apstraktne riječi u većoj mjeri aktiviraju neuronske krugove uključene u obradu emocija od konkretnih riječi (Vigliocco i sur., 2014).

Brojevi su istaknut primjer apstraktnih pojmova kod kojih se pojavljuju ista pitanja kao i kod reprezentacije drugih pojmova. Primjerice, utemeljuje li se značenje broja, odnosno njegova numerička veličina u perceptivnoj reprezentaciji ili je značenje određeno isključivo njihovom preciznom matematičkom definicijom putem jednoznačnoga obostranog preslikavanja i funkcije nasljednik (Izard i sur., 2008). Efekt numeričke veličine gdje ispitanici brže uspoređuju numerički manje brojeve $(2-3)$ u odnosu na veće $(6-7)$, efekt numeričke udaljenosti gdje ispitanici brže uspoređuju brojeve koji su numerički udaljeniji (2 - 7 u odnosu na $2-3$ ) (Moyer i Landauer, 1967, 1973), kao i efekt prostorno-numeričke povezanosti (engl. spatial numerical association of response codes, SNARC) gdje ispitanici brže reagiraju desnom rukom na veće brojeve, a lijevom rukom na manje brojeve (Dehaene i sur., 1993) sugeriraju da se značenje brojeva preslikava na analognu spacijalnu reprezentaciju koja se proteže horizontalno, pri čemu su manji brojevi smješteni lijevo, a veći brojevi desno kao na mentalnoj numeričkoj liniji (Dehaene, 2009, 2011; Feigenson i sur., 2004; Fischer i Shaki, 2014; Piazza, 2010; Šetić, 2016). Mentalna numerička linija dio je sustava za percepciju brojnosti koja omogućava približno određivanje koliko se objekata nalazi u vidnome polju. Taj sustav imaju i mnoge životinjske vrste, a funkcionalan je i kod male djece koja mogu razlikovati brojnost i prije nego što se počnu služiti brojevima kao verbalnim oznakama. Međutim, neka istraživanja sugeriraju da je sustav za reprezentaciju egzaktnih brojeva potpuno nezavisan od sustava za percepciju brojnosti te da mu nije potrebno utemeljenje (Butterworth, 2010; Leibovich i Ansari, 2016; Lyons i Ansari, 2015; Lyons i sur., 2012). Druga je mogućnost da se samo mali brojevi mogu utemeljiti u posebnome 
sustavu za brzo prebrojavanje malih skupova, odnosno subitizaciju (Dehaene, 2011; Feigenson i sur., 2004; Piazza, 2010; Šetić i Domijan, 2017; Šetić Beg i sur., 2021).

Teorija pojmovnih metafora također se može primijeniti na razumijevanje brojeva i drugih matematičkih pojmova (Lakoff i Nunez, 2000). Na primjer, elementarne aritmetičke operacije zbrajanja i oduzimanja mogu se preslikati na konkretno iskustvo konstrukcije objekta koji se sastoji od više dijelova. Pritom svaki dio predstavlja jedan broj, a rezultat primjene operacije novi je broj, odnosno konstruirani objekt. Dakle, aritmetičke su operacije shvaćene kao aktivnosti kojima objekt sastavljamo u veće cjeline ili rastavljamo na manje dijelove po određenim pravilima. Wilkie i Bodenhausen (2012) ispitali su mogu li se pojmovi parno i neparno utemeljiti putem metaforičkoga preslikavanja u bazičnoj dihotomiji kao što je spol. Pokazali su da ispitanici povezuju neparne brojeve s maskulinošću, a parne brojeve s femininošću. Međutim, u istraživanju su sudjelovale većinom žene (između 70 do $80 \%$ kroz četiri eksperimenta) te je ostalo nejasno mogu li se rezultati generalizirati i na muškarce. U drugoj studiji s većim i spolno balansiranim uzorkom repliciran je osnovni nalaz da se jednoznamenkasti neparni brojevi percipiraju kao maskulini, a parni kao feminini. Pritom je efekt izraženiji kod žena nego kod muškaraca. Nadalje, kod dvoznamenkastih brojeva muškarci i parne i neparne brojeve percipiraju kao maskuline, dok žene i u tome slučaju prave razliku tako da su im parni brojevi više feminini, a neparni brojevi maskulini (Wilkie i Bodenhausen, 2015).

Uz numeričku veličinu, parnost je temeljno obilježje brojeva (Shepard i sur., 1975). Broj se definira kao paran ako je djeljiv s 2, a ako nije, onda je neparan. Kognitivna reprezentacija parnosti ispituje se u kronometrijskim studijama u kojima se prezentira broj i traži se od ispitanika da što brže i točnije odrede njegovu parnost. Takva su istraživanja pokazala da ispitanici brže odgovaraju na parne nego na neparne brojeve. Taj se efekt pojavljuje i za brojke, kao i za riječi za brojeve, a razlika u brzini odgovora kreće se od 100 do $200 \mathrm{~ms}$ (Hines, 1990, 2010). Također, ispitanici brže reagiraju na parne brojeve desnom rukom, a na neparne brojeve lijevom rukom (Nuerk i sur., 2004). Taj je efekt nazvan lingvistička označenost kodova za odgovor (engl. markedness of response codes, MARC) jer se pretpostavlja da nastaje zbog lingvističke označenosti parova pojmova desno - lijevo i parno - neparno. Pritom su pojmovi lijevo i neparno lingvistički označeni jer predstavljaju suprotnost neoznačenim pojmovima desno i parno (Zimmer, 1964). Prethodna su istraživanja pokazala da ispitanici brže čitaju i razumijevaju rečenice koje sadrže lingvistički neoznačene pojmove (Sherman, 1973, 1976). Nadalje, lingvistički neoznačeni pojmovi obično imaju veću frekvenciju pojavljivanja u svakodnevnome govoru i usvajaju se u ranijoj dobi. Iz svega navedenoga može se izvući zaključak da će ispitanici brže reagirati u situaciji kad je lingvistička označenost pojmova usklađena (parno - desno i neparno - lijevo) nego kad je neusklađena (parno - lijevo i neparno - desno). 
Međutim, ljevoruki ljudi pokazuju obrnuti efekt od desnorukih jer brže reagiraju lijevom rukom na parne brojeve, a desnom rukom na neparne (Huber i sur., 2015). Pritom veličina efekta ovisi o stupnju ljevorukosti. Taj se nalaz ne uklapa u hipotezu o lingvističkoj označenosti koja bi trebala funkcionirati neovisno o ruci kojom ispitanik daje odgovor. S druge strane, nalaz se može objasniti afektivnim utjelovljenjem (Casasanto, 2009) prema kojemu ispitanici povezuju pozitivne pojmove $\mathrm{s}$ onom rukom kojom umješnije barataju u svakodnevnome životu. Desnoruki ljudi brže reagiraju na pozitivne pojmove desnom rukom, a ljevoruki ljudi brže reagiraju na pozitivne pojmove lijevom rukom (i obratno za negativne pojmove). Ako pretpostavimo da svi ispitanici parne brojeve doživljavaju kao pozitivne, a neparne brojeve kao negativne, onda se može očekivati upravo suprotan efekt brzine reagiranja na parne i neparne brojeve kod ljevorukih i desnorukih ljudi, kao što su dobili Huber i suradnici (2015).

Druga je hipoteza da su rezultati Hubera i suradnika (2015) posljedica strukturnoga slaganja između polariteta dimenzija podražaja i odgovora. Prema teoriji o korespondenciji polariteta (Proctor i Cho, 2006) u svim zadacima koji uključuju binarne podražajne dimenzije, kao i binarni odgovor, moguće je uspostaviti korespondenciju između istih polova na dimenzijama koja zatim dovodi do ubrzanja odgovora $\mathrm{i} / \mathrm{ili}$ veće procesne efikasnosti. Dakle, interakcija između parnosti i prostora možda je posljedica strukturnoga slaganja između dimenzija uključenih u eksperiment (paran/neparan i desnollijevo), a ne djelovanja kognitivnih mehanizama koji se nalaze u podlozi razumijevanja pojma broja. Prema teoriji svaki pol binarne dimenzije označen je kao pozitivan ili negativan, a brži i efikasniji odgovor očekuje se kad se poklope polovi na svim dimenzijama. Na primjer, odgovor paran može se označiti kao pozitivan, a odgovor neparan kao negativan. Isto tako, odgovor desnom rukom može se označiti kao pozitivan (kod desnorukih ispitanika), a odgovor lijevom rukom kao negativan. Dakle, desnoruki će ispitanici brže odgovarati desnom rukom na parne brojeve, a lijevom rukom na neparne brojeve zbog slaganja njihovih polariteta. Isto tako, ljevoruki će ispitanici brže odgovarati lijevom rukom na parne brojeve, a desnom rukom na neparne brojeve. Huber i suradnici (2015) istaknuli su da u njihovu istraživanju nije bilo moguće razlučiti koje od predloženih objašnjenja (afektivno utemeljenje ili korespondencija polariteta) bolje objašnjava dobivene rezultate.

Huber i suradnici (2015) ispitivali su samo pozitivne brojeve. Međutim, brojevi mogu biti i pozitivni i negativni, a predznak predstavlja važnu komponentu kognitivne reprezentacije broja. Pinhas i suradnici (2014) pokazali su da znakovi plus i minus induciraju prostornu pristranost slično kao i mali i veliki brojevi. Preciznije, ispitanici brže reagiraju na znak plus desnom rukom, a na znak minus lijevom rukom. Taj je efekt povezan s mentalnom aritmetikom jer zbrajanje pomiče lokaciju na mentalnoj numeričkoj liniji udesno, a oduzimanje je pomiče ulijevo. To je posljedica činjenice da se znakovi plus i minus koriste u binarnim operacijama gdje označavaju zbrajanje i oduzimanje. Nadalje, Pinhas i suradnici (2014) ističu da znakovi 
plus/minus imaju svoje značenje i izvan matematike jer ih se često koristi kao oznake za više/manje. U skladu s teorijom o afektivnome utemeljenju (Kousta i sur., 2011; Vigliocco i sur., 2013, 2014) možemo pretpostaviti da je mentalna reprezentacija znakova plus/minus također afektivno obojena. Dakle, osnovna je hipoteza da se mehanizam afektivnoga utemeljenja može generalizirati na apstraktne matematičke pojmove. Indirektnu podršku toj hipotezi daju podaci o valenciji riječi kao što su zbrojiti (6.23), oduzeti (4.25), pozitivno (7.57) i negativno (2.52) preuzeti iz baze afektivnih normi za 13915 engleskih riječi (Warriner i sur., 2013). Procjene valencije dane su u rasponu od 1 do 9 , pri čemu 1 označava izrazito negativnu, a 9 izrazito pozitivnu riječ, tako da veća vrijednost označava afektivno pozitivniju riječ. Iako u tome istraživanju nije direktno ispitana afektivna evaluacija znakova plus i minus, možemo pretpostaviti da bi valencija znaka plus mogla biti negdje između procjena za riječ zbrojiti i riječ pozitivno, dok bi valencija znaka minus mogla biti negdje u rasponu između procjena za riječ oduzeti i riječ negativno.

$\mathrm{Na}$ osnovi prethodnih razmatranja možemo postaviti hipotezu da je pozitivni predznak povezan s pozitivnim afektivnim polom. Zbog toga će pozitivni predznak ubrzati obradu njemu afektivno sukladnih parnih brojeva u odnosu na nesukladne neparne brojeve. $\mathrm{S}$ druge strane, negativni je predznak povezan $\mathrm{s}$ negativnim afektivnim polom te će zbog toga ubrzati obradu njemu sukladnih neparnih brojeva u odnosu na parne brojeve. Nadalje, moguće je razlikovati dvije vrste afektivnoga utemeljenja: centralno i periferno. Centralno se utemeljenje odnosi na procese preslikavanja značenja između pojmovne i afektivne domene koji se odvijaju neovisno od pripreme motoričkoga odgovora (Kousta i sur., 2011; Vigliocco i sur., 2013, 2014). S druge strane, periferno će se utemeljenje manifestirati u interakciji s rukom kojom se daje odgovor jer su pozitivni pojmovi povezani s dominantnom rukom, a negativni pojmovi s nedominantnom rukom (Casasanto, 2009). Također, kao i u istraživanju Hubera i suradnika (2015), i ovdje treba uzeti u obzir djelovanje korespondencije polariteta (Proctor i Cho, 2006).

Cilj je ovoga istraživanja ispitati postoji li sukladnost između pariteta i predznaka jednoznamenkastih brojeva. Provedena su dva kronometrijska eksperimenta. U prvome su eksperimentu ispitanici određivali je li prezentirani broj u rasponu od -9 do 9 paran ili neparan. Dobivena je dvosmjerna interakcija između predznaka i pariteta jer su ispitanici brže i efikasnije reagirali na pozitivne u odnosu na negativne parne brojeve, kao i na negativne u odnosu na pozitivne neparne brojeve. Nadalje, nije bilo trosmjerne interakcije između predznaka, pariteta i ruke. Taj je nalaz u skladu i s teorijom o centralnome afektivnom utemeljenju, kao i s teorijom o korespondenciji polariteta. Da bismo razdvojili utjecaj centralnoga afektivnog utemeljenja od korespondencije polariteta, proveden je drugi eksperiment u kojemu je odgovor na zadatak bio ortogonalan s obzirom na paritet broja jer su ispitanici određivali je li broj veći ili manji od 5. Dobivena je složenija trosmjerna interakcija između predznaka, pariteta i odgovora koja djelomično ide u prilog 
objema predloženim teorijama. Kao ni u prvome eksperimentu, dobiveni efekt nije bio pod utjecajem ruke kojom se daje odgovor.

\section{Eksperiment 1.}

\section{Metoda}

U Eksperimentu 1. korišten je faktorski nacrt $2 \times 2 \times 2 \times 2$, a nezavisne su varijable bile sljedeće:

1. Predznak broja: pozitivan ili negativan;

2. Paritet (ili vrsta odgovora): paran (odgovor DA) ili neparan (odgovor NE);

3. Numerička veličina broja: mali (1 - 4) ili veliki $(6-9)$ brojevi;

4. Ruka kojom se daje odgovor DA: lijeva ili desna (polovica ispitanika odgovarala je DA lijevom rukom i NE desnom rukom, a druga polovica ispitanika imala je obrnuti raspored odgovora).

Zavisne varijable $\mathrm{u}$ eksperimentu bile su izborno vrijeme reakcije mjereno $\mathrm{u}$ milisekundama i točnost odgovora iskazana kao postotak točnih odgovora. Da bi se kontrolirala pojava trgovine između brzine i točnosti, kreirana je kompozitna varijabla koja se naziva procesna efikasnost (Bruyer i Brysbaert, 2011). Ona se dobije kad se proporcija točnih odgovora podijeli s vremenom reakcije u sekundama. Zasebno su prikazane analize na vremenu reakcije i na procesnoj efikasnosti.

\section{Ispitanici}

U eksperimentu je sudjelovalo 45 studenata preddiplomskoga studija psihologije Filozofskoga fakulteta u Rijeci, od čega 38 studentica i 7 studenata, u rasponu dobi od 19 do 25 godina. Sudjelovanje u eksperimentu bilo je dobrovoljno, a nagrađivalo se bodovima za eksperimentalne sate. Svi su ispitanici izjavili da im je desna ruka dominantna.

\section{Pribor}

Eksperiment je proveden na osobnome računalu, a podražaji su prezentirani u računalnome programu E-prime 2.0. Odgovori ispitanika bilježeni su pomoću uređaja Empirisoft za mjerenje vremena reakcije s milisekundnom preciznošću.

\section{Postupak}

Ispitivanje je provedeno individualno sa svakim ispitanikom u zvučno izoliranoj prostoriji. Podražaji u ovome eksperimentu bili su brojevi od -9 do 9 , bez brojeva $-5,0$ i 5 . Brojevi -5 i 5 isključeni su da bi skupovi parnih i neparnih brojeva bili uravnoteženi, odnosno da bi se oba skupa sastojala od četiri različite znamenke. 
Svaki je broj bio prezentiran u sredini ekrana i pojavio se deset puta, što je ukupno sačinjavalo 160 pokušaja. Redoslijed prezentacije brojeva bio je određen po slučaju za svakoga ispitanika, uz pravilo da se ne mogu prezentirati četiri parna ili neparna broja uzastopce. Svaki je pokušaj započeo prezentacijom fiksacijskoga znaka (X) na sredini ekrana u trajanju od $500 \mathrm{~ms}$. Nakon fiksacijskoga znaka uslijedila je prezentacija broja (u fontu Arial, veličine 42) koji je ostao na ekranu do trenutka odgovora. Ispitanicima nije davana povratna informacija o uratku. Zadatak je ispitanika bio odgovoriti je li prezentirani broj paran ili nije pritiskom na tipku DA ili tipku NE (krajnje tipke na uređaju za mjerenje vremena reakcije). Polovica ispitanika odgovarala je DA pritiskom kažiprsta lijeve ruke na lijevu tipku, a druga polovica ispitanika pritiskom kažiprsta desne ruke na desnu tipku (i obratno za odgovor NE).

\section{Rezultati}

\section{Analiza vremena reakcije}

Iz analize vremena reakcije isključeni su netočni odgovori (3.9 \% podataka), kao i odgovori brži od $150 \mathrm{~ms}$ i sporiji od $2500 \mathrm{~ms}$ ( $0.1 \%$ podataka). Na preostalim podacima izračunane su aritmetičke sredine za svakoga ispitanika po svakome uvjetu. $\mathrm{Na}$ aritmetičkim je sredinama provedena četverosmjerna $(2 \times 2 \times 2 \times 2)$ analiza varijance s ponavljanim mjerenjima na faktorima predznak (plus ili minus), parnost (paran ili neparan) i veličina (mali ili veliki), dok je ruka (lijeva ili desna) bila faktor nezavisnih grupa. Analiza ANOVA pokazala je da postoji statistički značajan glavni efekt predznaka, $F(1,43)=13.96, p<.001, \eta^{2}=.24$, pri čemu su ispitanici brže odgovarali na pozitivne $(M=505 \mathrm{~ms}, S E=5.76)$ nego na negativne brojeve $(M$ $=521 \mathrm{~ms}, S E=6.68)$. Glavni efekt parnosti nije statistički značajan, $F(1,43)=4.00$, $p=.052, \eta^{2}=.09$, kao ni glavni efekt veličine, $F(1,43)<1, p>.250, \eta^{2}<.01$, i ruke, $F(1,43)<1, p>.250, \eta^{2}<.01$. Dvosmjerna interakcija između predznaka i parnosti statistički je značajna, $F(1,43)=25.08, p<.001, \eta^{2}=.37$, kao i interakcija između predznaka i veličine, $F(1,43)=8.47, p=.006, \eta^{2}=.16$, interakcija između parnosti i veličine, $F(1,43)=8.75, p=.005, \eta^{2}=.17$, te interakcija između parnosti i ruke, $F(1,43)=6.40, p=.015, \eta^{2}=.13$. Dvosmjerna interakcija između predznaka i ruke nije statistički značajna, $F(1,43)<1, p>.250, \eta^{2}<.01$, kao ni interakcija između veličine i ruke, $F(1,43)=3.43, p=.071, \eta^{2}=.07$. Trosmjerna interakcija između predznaka, parnosti i veličine nije statistički značajna, $F(1,43)<1, p>.250, \eta^{2}<$ .01 , kao ni interakcija između predznaka, veličine i ruke, $F(1,43)=1.54, p=.222$, $\eta^{2}=.03$, interakcija između predznaka, parnosti i ruke, $F(1,43)<1, p>.250, \eta^{2}<$ .01 , te interakcija između parnosti, veličine i ruke, $F(1,43)<1, p>.250, \eta^{2}<.01$. Nakraju, četverosmjerna interakcija također nije statistički značajna, $F(1,43)=4.04$, $p=.051, \eta^{2}=.09$.

$\mathrm{S}$ obzirom na to da je od najveće teorijske važnosti interakcija između predznaka i parnosti, detaljnije ćemo istražiti njezin izvor. Analiza jednostavnih 
efekata uz Holmovu korekciju značajnosti za višestruke usporedbe pokazala je da su kod parnih brojeva ispitanici za $39 \mathrm{~ms}$ brže reagirali na pozitivan broj nego na negativan broj, $F(1,43)=39.19, p<.001, \eta^{2}=.48$. S druge strane, kod neparnih brojeva nije bilo statistički značajne razlike između reakcije na pozitivan i negativan broj, $F(1,43)=1.46, p=.233, \eta^{2}=.03$. Deskriptivni podaci za dvosmjernu interakciju između predznaka i pariteta kod vremena reakcije prikazani su na Slici $1 \mathrm{~A}$.

\section{Analiza procesne efikasnosti}

Provedena je četverosmjerna $(2 \times 2 \times 2 \times 2)$ analiza ANOVA s ponavljanim mjerenjima na faktorima predznak (plus ili minus), parnost (paran ili neparan) $\mathrm{i}$ veličina (mali ili veliki), dok je ruka (lijeva ili desna) bila faktor nezavisnih grupa. Analiza ANOVA pokazala je da postoji statistički značajan glavni efekt predznaka, $F(1,43)=11.92, p=.001, \eta^{2}=.22$, pri čemu su ispitanici pokazali veću procesnu efikasnost za pozitivne $(M=1.95, S E=0.02)$ nego za negativne brojeve $(M=1.90$, $S E=0.02$ ). Glavni efekt parnosti nije statistički značajan, $F(1,43)=1.19, p=.282$, $\eta^{2}=.03$, kao ni glavni efekt veličine, $F(1,43)<1, p>.250, \eta^{2}<.01$, i ruke, $F(1,43)$ $<1, p>.250, \eta^{2}<.01$. Dvosmjerna interakcija između predznaka i parnosti statistički je značajna, $F(1,43)=42.27, p<.001, \eta^{2}=.50$, kao i interakcija između predznaka i veličine, $F(1,43)=5.91, p=.019, \eta^{2}=.12$, interakcija između parnosti i veličine, $F(1,43)=10.72, p=.002, \eta^{2}=.20$, te interakcija između parnosti i ruke, $F(1,43)=$ $5.09, p=.029, \eta^{2}=.11$. Dvosmjerna interakcija između predznaka i ruke nije statistički značajna, $F(1,43)<1, p>.250, \eta^{2}<.01$, kao ni interakcija između veličine i ruke, $F(1,43)=2.18, p=.147, \eta^{2}=.05$. Trosmjerna interakcija između predznaka, parnosti i veličine nije statistički značajna, $F(1,43)<1, p>.250, \eta^{2}<.01$, kao ni interakcija između predznaka, veličine i ruke, $F(1,43)<1, p>.250, \eta^{2}<.01$, interakcija između predznaka, parnosti i ruke, $F(1,43)<1, p>.250, \eta^{2}<.01$, te interakcija između parnosti, veličine i ruke, $F(1,43)<1, p>.250, \eta^{2}<.01$. Nakraju, četverosmjerna interakcija također nije statistički značajna, $F(1,43)=1.51, p=.225$, $\eta^{2}=.03$.

Analiza jednostavnih efekata za dvosmjernu interakciju između predznaka i parnosti pokazala je da su kod parnih brojeva ispitanici pokazali veću procesnu efikasnost kad je bio prezentiran pozitivan broj nego kad je bio prezentiran negativan broj, $F(1,43)=38.30, p<.001, \eta^{2}=.47$. S druge strane, kod neparnih su brojeva ispitanici pokazali manju procesnu efikasnost za pozitivan broj nego za negativan broj, $F(1,43)=16.67, p<.001, \eta^{2}=.28$. Deskriptivni podaci za dvosmjernu interakciju između predznaka i pariteta kod procesne efikasnosti prikazani su na Slici $1 B$. 


\section{Slika 1.}

Dvosmjerna interakcija između predznaka i parnosti

A

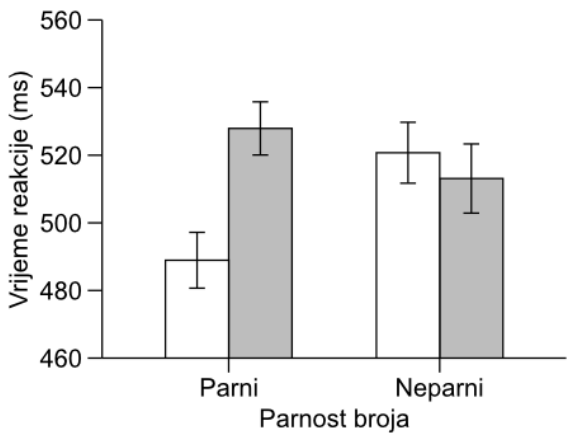

B

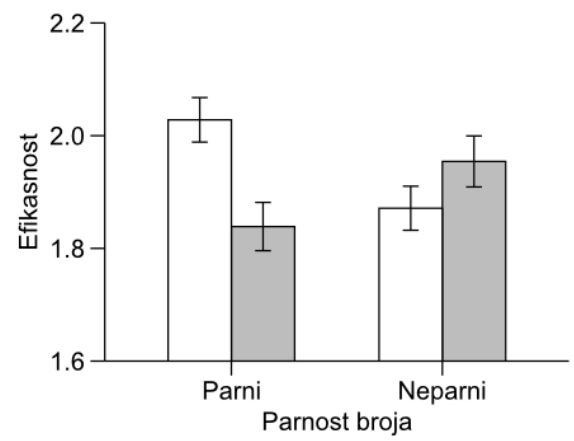

Plus $\square$ Minus

Napomena: Prosječno vrijeme reakcije u milisekundama (A) i prosječna procesna efikasnost (B) prikazani su u funkciji parnosti (parni i neparni brojevi) i njihova predznaka (plus i minus). Linije oko aritmetičkih sredina predstavljaju $95 \%$-tne intervale pouzdanosti.

\section{Eksperiment 2.}

\section{Metoda}

\section{Ispitanici}

U eksperimentu je sudjelovalo 50 studenata Filozofskoga fakulteta Sveučilišta u Mostaru, od čega 42 studentice i 8 studenata, u rasponu dobi od 19 do 24 godine. Sudjelovanje u eksperimentu bilo je dobrovoljno, a nagrađivalo se bodovima za eksperimentalne sate. Kao i u prvome eksperimentu, uključeni su samo oni ispitanici koji su izjavili da im je desna ruka dominantna.

\section{Pribor}

Korišteni su isti računalni program i uređaj za mjerenje vremena reakcije kao i u prvome eksperimentu. Kao podražaji korišteni su isti brojevi u rasponu od -9 do 9 bez $-5,0$ i 5 .

\section{Postupak}

Postupak je bio identičan kao i u prvome eksperimentu, osim što je zadatak bio odrediti je li broj veći ili manji od 5, pri čemu treba zanemariti predznak koji je prikazan uz broj. Polovica je ispitanika odgovarala pritiskom na lijevu tipku kad je 
prikazani broj veći od 5 i pritiskom na desnu tipku kad je broj manji od 5. Druga polovica ispitanika imala je obrnuti raspored tipki za odgovor.

\section{Rezultati}

\section{Analiza vremena reakcije}

Iz analize vremena reakcije isključeni su netočni odgovori (1.4\% podataka), kao i odgovori brži od $150 \mathrm{~ms}$ i sporiji od $2500 \mathrm{~ms}(0.2 \%$ podataka).

Provedena je četverosmjerna $(2 \times 2 \times 2 \times 2)$ analiza ANOVA s ponavljanim mjerenjima na faktorima predznak (pozitivan ili negativan), parnost (paran ili neparan) i veličina (mali ili veliki), dok je ruka (lijeva ili desna) bila faktor nezavisnih grupa. Analiza ANOVA pokazala je da postoji statistički značajan glavni efekt predznaka, $F(1,48)=12.90, p<.001, \eta^{2}=.21$, pri čemu su ispitanici brže odgovarali na pozitivne $(M=614 \mathrm{~ms}, S E=8.43)$ nego na negativne brojeve $(M=632 \mathrm{~ms}, S E=$ 9.40). Glavni efekt parnosti također je statistički značajan, $F(1,48)=8.13, p=.006$, $\eta^{2}=.14$, pri čemu su ispitanici sporije reagirali na parne $(M=629 \mathrm{~ms}, S E=8.42)$ nego na neparne brojeve $(M=617 \mathrm{~ms}, S E=9.43)$. $S$ druge strane, nije bilo glavnoga efekta veličine, $F(1,48)<1, p>.250, \eta^{2}<.01$, i ruke, $F(1,48)<1, p>.250, \eta^{2}<$ .01. Dvosmjerna interakcija između predznaka i veličine statistički je značajna, $F(1,48)=5.62, p=.022, \eta^{2}=.10$. Dvosmjerna interakcija između pariteta i ruke nije statistički značajna, $F(1,48)=2.53, p=.118, \eta^{2}=.05$, kao ni sve ostale dvosmjerne interakcije (svi $F$-ovi $<1.5, p$-ovi $>.250$ i $\eta^{2}<.03$ ). Trosmjerna interakcija između predznaka, pariteta i veličine statistički je značajna, $F(1,48)=4.27, p=.044, \eta^{2}=$ .08 . Sve ostale trosmjerne interakcije nisu statistički značajne (svi $F$-ovi $<1.5, p$-ovi $\left.>.250 \mathrm{i} \eta^{2}<.03\right)$. Četverosmjerna interakcija također nije statistički značajna, $F(1,48)<1, p>.250, \eta^{2}=.02$.

Analiza jednostavnih efekata za trosmjernu interakciju između predznaka, parnosti $i$ veličine pokazala je da su pri prezentaciji velikih brojeva ispitanici bili 46 ms brži u reagiranju na pozitivne parne u odnosu na negativne parne brojeve, $F(1,48)=22.22, p<.001, \eta^{2}=.32$. S druge strane, nije bilo razlike između pozitivnih i negativnih neparnih brojeva, $F(1,48)=3.77, p=.175, \eta^{2}=.07$ (Slika 2A). Pri prezentaciji malih brojeva nije bilo statistički značajne razlike između pozitivnih i negativnih parnih brojeva, $F(1,48)<1, p>.250, \eta^{2}<.01$, kao ni razlike između pozitivnih i negativnih neparnih brojeva, $F(1,48)<1, p>.250, \eta^{2}=.01$ (Slika 2B).

\section{Analiza procesne efikasnosti}

Provedena je četverosmjerna $(2 \times 2 \times 2 \times 2)$ analiza ANOVA s ponavljanim mjerenjima na faktorima predznak (pozitivan ili negativan), parnost (paran ili neparan) i veličina (mali ili veliki), dok je ruka (lijeva ili desna) bila faktor nezavisnih grupa. Analiza ANOVA pokazala je da postoji statistički značajan glavni efekt predznaka, $F(1,48)=7.63, p=.008, \eta^{2}=.14$, pri čemu su ispitanici pokazali veću 
procesnu efikasnost za pozitivne $(M=1.66, S E=0.021)$ nego za negativne brojeve $(M=1.63, S E=0.023)$. Glavni efekt parnosti također je statistički značajan, $F(1,48)$ $=27.88, p<.001, \eta^{2}=.37$, pri čemu su ispitanici pokazali manju efikasnost za parne $(M=1.61, S E=0.021)$ nego za neparne brojeve $(M=1.67, S E=0.023)$. S druge strane, nije bilo glavnoga efekta veličine, $F(1,48)<1, p>.250, \eta^{2}<.01$, i ruke, $F(1,48)<1, p>.250, \eta^{2}<.01$. Dvosmjerna interakcija između predznaka i veličine statistički je značajna, $F(1,48)=5.21, p=.027, \eta^{2}=.10$. Dvosmjerna interakcija između pariteta i ruke nije statistički značajna, $F(1,48)=1.39, p=.245, \eta^{2}=.03$,

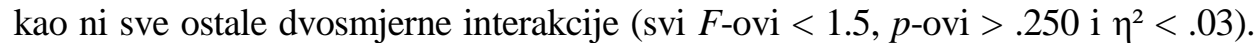
Trosmjerna interakcija između predznaka, pariteta i veličine blizu je granice statističke značajnosti, $F(1,48)=3.94, p=.053, \eta^{2}=.08$, a trosmjerna interakcija između parnosti, veličine i ruke statistički je značajna, $F(1,48)=5.14, p=.028$, $\eta^{2}=.10$. Preostale dvije trosmjerne interakcije nisu statistički značajne $(F$-ovi $<1$, $p$-ovi $\left.>.250 \mathrm{i} \eta^{2}<.03\right)$. Četverosmjerna interakcija također nije statistički značajna, $F(1,48)<1, p>.250, \eta^{2}<.01$.

Trosmjerna interakcija između predznaka, parnosti i veličine blizu je granice statističke značajnosti, a zbog njezine teorijske važnosti za hipoteze ovoga istraživanja napravljena je analiza jednostavnih efekata koja je pokazala da su pri prezentaciji velikih brojeva ispitanici pokazali veću procesnu efikasnost kad su reagirali na pozitivne parne u odnosu na negativne parne brojeve, $F(1,48)=13.50$, $p=.002, \eta^{2}=.22$. S druge strane, nije bilo razlike u procesnoj efikasnosti između pozitivnih i negativnih neparnih brojeva, $F(1,48)=3.77, p=.174, \eta^{2}=.07$ (Slika 2C). Pri prezentaciji malih brojeva nije bilo statistički značajne razlike između pozitivnih i negativnih parnih brojeva, $F(1,48)<1, p>.250, \eta^{2}=.01$, kao ni razlike između pozitivnih i negativnih neparnih brojeva, $F(1,48)<1, p>.250, \eta^{2}<.01$ (Slika 2D).

\section{Rasprava}

Provedena su dva eksperimenta s ciljem ispitivanja mehanizama koji se nalaze u podlozi razumijevanja apstraktnih pojmova kao što su brojevi. U prvome su eksperimentu ispitanici imali zadatak što brže i točnije odgovoriti je li prezentirani jednoznamenkasti broj paran ili neparan. Pojavila se dvosmjerna interakcija između predznaka i brojnosti. Analiza jednostavnih efekata pokazala je da su ispitanici bili efikasniji u obradi kad je paran broj bio pozitivan nego kad je bio negativan. S druge strane, za neparne su brojeve ispitanici bili efikasniji kad je neparan broj bio negativan nego kad je bio pozitivan. Ako matematički predznak shvatimo kao oblik afektivne evaluacije, pri čemu implicitno pozitivni predznak predstavlja afektivno pozitivan znak, dok negativni predznak predstavlja afektivno negativan znak, rezultati prvoga eksperimenta podupiru teoriju centralnoga afektivnog utemeljenja (Kousta i sur., 2011; Vigliocco i sur., 2013, 2014). U ovome eksperimentu nije bilo eksplicitnoga aktiviranja pojma spol, što sugerira da rezultati ne proizlaze iz 


\section{Slika 2.}

Trosmjerna interakcija između predznaka, parnosti $i$ veličine broja

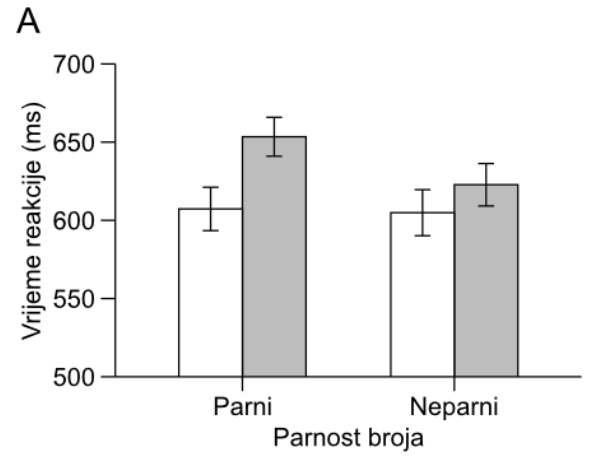

C

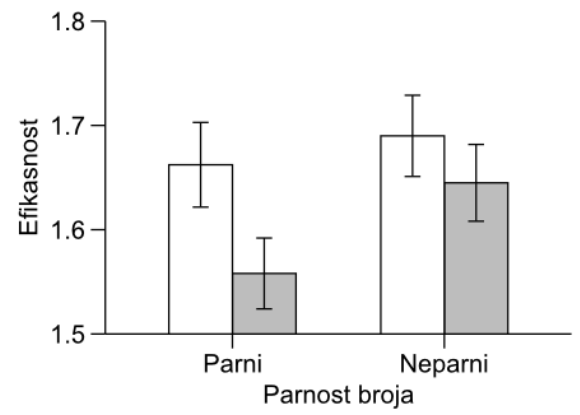

B

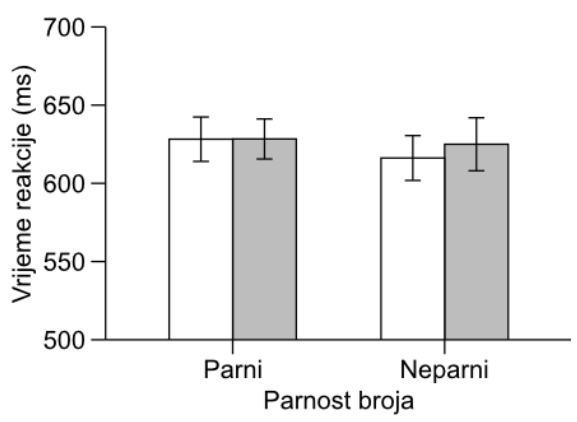

D

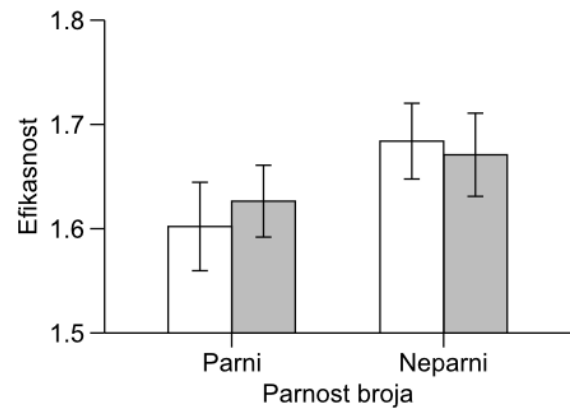

Predznak $\square$ Plus $\square$ Minus

Napomena: Prosječno vrijeme reakcije u milisekundama prikazano je u funkciji parnosti (parni i neparni brojevi) i predznaka (plus i minus) kad su prikazani (A) veliki brojevi (odgovor DA) i kad su prikazani (B) mali brojevi (odgovor NE). Prosječna procesna efikasnost prikazana je u funkciji parnosti (parni i neparni brojevi) i predznaka (plus i minus) kad su prikazani (C) veliki brojevi (odgovor DA) i kad su prikazani (D) mali brojevi (odgovor NE). Linije oko aritmetičkih sredina predstavljaju $95 \%$-tne intervale pouzdanosti.

metaforičkoga preslikavanja između spola i brojeva kao što su dobili Wilkie i Bodenhausen $(2012,2015)$. Međutim, ostaje mogućnost da je spol ispitanika utjecao na rezultate. Nažalost, to nismo mogli direktno provjeriti jer je u uzorku bilo mnogo više studentica nego studenata zbog spolnoga disbalansa koji je općenito prisutan na studijima psihologije u Hrvatskoj i Bosni i Hercegovini. Također, treba istaknuti da se dobiveni efekt ne može objasniti efektom MARC, odnosno lingvističkom označenošću kodova za odgovor jer nije bilo trosmjerne interakcije s rukom, kao ni četverosmjerne interakcije koje bi sugerirale razlike u odgovoru lijevom i desnom rukom (Nuerk i sur., 2004). Taj nalaz također ne ide u prilog hipotezi o perifernome afektivnom utemeljenju prema kojoj se na pozitivne pojmove brže reagira 
dominantnom, a na negativne pojmove nedominantnom rukom (Casasanto, 2009). U našemu su istraživanju svi ispitanici bili desnoruki te bi se očekivalo da će desnom rukom brže reagirati na parne i pozitivne brojeve, a lijevom rukom na neparne $\mathrm{i}$ negativne brojeve. Stoga ćemo u nastavku raspravljati samo o centralnome afektivnom utemeljenju koje se odvija neovisno o izboru motoričkoga odgovora (Kousta i sur., 2011; Vigliocco i sur., 2013, 2014).

Problem je što se dvosmjerna interakcija dobivena u prvome eksperimentu može objasniti i teorijom korespondencije polariteta, kao što je opisano u Uvodu (Proctor i Cho, 2006). Teorija predviđa da će ispitanici brže i efikasnije reagirati na pozitivne parne nego na negativne parne brojeve jer parni i pozitivni brojevi imaju isti pozitivni polaritet koji će ubrzati ispitanikovu reakciju. Na isti način, teorija predviđa da će ispitanici brže i efikasnije reagirati na negativne neparne brojeve $u$ odnosu na pozitivne neparne brojeve jer dijele isti negativni polaritet, što je i dobiveno. Zanimljivo je spomenuti da se korespondencijom polariteta mogu objasniti i mnogi drugi nalazi koji se uzimaju kao potvrda za teoriju metaforičkoga preslikavanja, ali o tome su mišljenja podijeljena (Dolscheid i Casasanto, 2015; Lakens, 2012; Santiago i Lakens, 2015). Također, teorija može objasniti i pojave u području numeričke kognicije, kao što je brže reagiranje na male (velike) brojeve lijevom (desnom) rukom, odnosno efekt SNARC (Dehaene i sur., 1993). Teorija pretpostavlja da se brojevi kategoriziraju u dvije kategorije: mali/veliki, a prostor u kategorije lijevo/desno. Pritom su mali brojevi i lijeva strana prostora označeni kao negativni pol, a veliki brojevi i desna strana kao pozitivni pol. Kao posljedica slaganja polariteta dolazi od bržega reagiranja lijevom rukom na male brojeve, a desnom rukom na velike brojeve (Bae i sur., 2009; Gevers i sur., 2006; Proctor i Cho, 2006). Slično objašnjenje efekta SNARC nudi i model konceptualnoga kodiranja u kojemu se polovi binarne kategorije (mali/veliki) u asocijativnoj mreži povezuju s polovima drugih binarnih dimenzija, kao što su lijevoldesno ili bliželdalje (Gevers i sur., 2006, 2010; Santens i Gevers, 2008).

Da bismo razdvojili djelovanje centralnoga afektivnog utemeljenja od korespondencije polariteta, proveden je drugi eksperiment u kojemu je korišten zadatak određivanja veličine broja. Ispitanici su trebali odrediti je li prezentirani broj veći ili manji od 5. Pritom su trebali zanemariti predznak broja. Naime, kod negativnih brojeva numerička veličina obrnuto je orijentirana u odnosu na pozitivne brojeve, tako da je -1 veći broj od -9 . Ovdje smo pretpostavili da ispitanici mogu razdvojiti broj od njegova predznaka. Opravdanje za takav postupak prethodna su istraživanja koja su pokazala da ispitanici ne doživljavaju negativne brojeve kao cjelinu, nego ih mentalno konstruiraju iz dviju sastavnih komponenti: broja i predznaka. Na primjer, Fischer i Rottmann (2005) tražili su od ispitanika da odrede paritet broja. Pritom su brojevi prezentirani u tri bloka pokušaja. U jednome su bloku prezentirani samo pozitivni brojevi, u drugome bloku samo negativni, a u trećemu bloku bili su izmiješani pozitivni i negativni brojevi. Neovisno o vrsti bloka, pojavila se negativna korelacija između razlike u vremenu odgovora danoga desnom i lijevom 
rukom i numeričke veličine pozitivnih brojeva. To je u skladu s mnogim istraživanjima efekta SNARC koja su pokazala da ispitanici brže reagiraju na male brojeve lijevom rukom, a na velike brojeve desnom rukom (Dehaene i sur., 1993). Zanimljivo, kod negativnih je brojeva dobivena pozitivna korelacija, što znači da su ispitanici ignorirali predznak i tretirali negativne brojeve kao pozitivne. Pritom treba imati na umu da je kod računanja tih korelacija kao varijabla korištena matematička definicija numeričke veličine pa je broj -1 veći od -9 , što je dovelo do pozitivne korelacije s razlikom u vremenu reakcije danom desnom i lijevom rukom. Do istoga su zaključka došla istraživanja kompatibilnosti numeričke i fizičke veličine u kojima se dva broja uspoređuju po numeričkoj ili fizičkoj veličini. Takve su usporedbe također pokazale da ispitanici ignoriraju predznak kod usporedbe dva negativna broja (Pinhas i Tzelgov, 2012; Tzelgov i sur., 2009).

U drugome je eksperimentu polaritet odgovora (veći ili manji od 5) bio ortogonalan na polaritet pariteta i predznaka pa se time može razdvojiti djelovanje korespondencije polariteta od djelovanja centralnoga afektivnog utemeljenja. U drugome je eksperimentu dobivena složenija trosmjerna interakcija između predznaka, pariteta i odgovora. Zanimljivo je da analiza jednostavnih efekata ne podupire u potpunosti ni teoriju centralnoga afektivnog utemeljenja, ni teoriju korespondencije polariteta. Naime, teorija afektivnoga utemeljenja pretpostavlja da bi se dvosmjerna interakcija između predznaka i pariteta trebala replicirati i u drugome eksperimentu, odnosno da promjena vrste odgovora ne bi trebala utjecati na rezultate. S druge strane, teorija korespondencije polariteta predviđa trosmjernu interakciju jer se u situaciji s tri binarne dimenzije moraju sve tri slagati da bi proizvele brži i efikasniji odgovor. Pritom smo pretpostavili da je broj veći od 5 označen kao pozitivan, a broj manji od 5 kao negativan. Istu pretpostavku da su mali brojevi označeni negativnim, a veliki brojevi pozitivnim polaritetom koristili su Bae i suradnici (2009), Gevers i suradnici (2006) te Proctor i Cho (2006) u objašnjenju efekta SNARC. Uz takav raspored polariteta po dimenzijama, teorija predviđa da bi ispitanici trebali brže i efikasnije reagirati kod prezentacije većega parnog broja kad je pozitivan nego kad je negativan. Nasuprot tomu, ispitanici bi trebali brže i efikasnije reagirati kod prezentacije manjega neparnog broja kad je negativan nego kad je pozitivan. Međutim, dobiven je samo očekivani efekt za veće parne brojeve, ali ne i za manje neparne brojeve.

S obzirom na složenost rezultata drugoga eksperimenta, možemo zaključiti da će biti potrebna daljnja istraživanja toga zanimljivog fenomena. Moguće je da zadatak određivanja veličine broja nije najbolji način za razdvajanje djelovanja centralnoga afektivnog utemeljenja od korespondencije polariteta te će biti potrebno osmisliti nove zadatke. Naime, zadatak određivanja veličine zahtijeva aktiviranje reprezentacije numeričke veličine broja koja se oslanja na mentalnu numeričku liniju, kako je opisano u Uvodu (Dehaene, 2011; Fischer i Shaki, 2014; Šetić, 2016). $\mathrm{S}$ druge strane, paritet je binarni pojam značenje kojega se dohvaća direktno iz dugoročnoga pamćenja. Stoga je moguće da se prilikom određivanja veličine broja 
aktiviraju i sukobljavaju različite kognitivne reprezentacije čiji se efekti na konačan odgovor međusobno poništavaju. Nadalje, u provedenim je istraživanjima afektivna evaluacija inducirana posredno putem predznaka, gdje smo pretpostavili da postoji veza između znaka plus i pozitivnoga te između znaka minus i negativnoga afektivnog tona. Direktniji test uloge afektivne komponente u reprezentaciji pariteta bila bi paradigma afektivne pripreme ili udešenosti (engl. affective priming) u kojoj se kratko prezentira afektivno obojena riječ ili slika prije prezentacije ciljnoga pojma na koji ispitanik mora reagirati (Klauer i Musch, 2003). Također, u zadatku određivanja pariteta trebalo bi izbjeći formiranje polariteta odgovora tako da se koristi zadatak u kojemu ispitanici reagiraju samo na jednu vrstu podražaja, kao što je to slučaj u zadatku idi/ne idi (engl. go/no-go task; Gomez i sur., 2007). Primjerice, zadatak može biti pritisnuti tipku za odgovor kad je broj paran i suzdržati se od odgovora kad je broj neparan.

Na kraju, možemo zaključiti da postoji interakcija između polariteta i parnosti jednoznamenkastih brojeva koja dosad nije opisana u literaturi. Međutim, priroda te interakcije nije do kraja razjašnjena jer se rezultati mogu tumačiti kroz dvije suprotstavljene teorije: centralno afektivno utemeljenje i korespondenciju polariteta.

\section{Literatura}

Bae, G. Y., Choi, J. M., Cho, Y. S. i Proctor, R. W. (2009). Transfer of magnitude and spatial mappings to the SNARC effect for parity judgments. Journal of Experimental Psychology: Learning, Memory, and Cognition, 35(6), 1506-1521. https://doi.org/10. 1037/a0017257

Barsalou, L. W. (1999). Perceptual symbol systems. Behavioral and Brain Sciences, 22, 577 660. https://doi.org/10.1017/s0140525x99002149

Barsalou, L. W. (2003). Situated simulation in the human conceptual system. Language and Cognitive Processes, 18, 513-562. https://doi.org/10.1080/01690960344000026

Barsalou, L. W. (2008). Grounded cognition. Annual Review of Psychology, 59, 617-645. https://doi.org/10.1146/annurev.psych.59.103006.093639

Barsalou, L. W. (2020). Challenges and opportunities for grounding cognition. Journal of Cognition, 3, 31. https://doi.org/10.5334/joc.116

Borghi, A. M. (2020). A future of words: Language and the challenge of abstract concepts. Journal of Cognition, 3, 42. https://doi.org/10.5334/joc.134

Borghi, A. M., Binkofski, F., Castelfranchi, C., Cimatti, F., Scorolli, C. i Tummolini, L. (2017). The challenge of abstract concepts. Psychological Bulletin, 143, 263-292. https://doi.org/10.1037/bul0000089 
Bruyer, R. i Brysbaert, M. (2011). Combining speed and accuracy in cognitive psychology: Is the inverse efficiency score (IES) a better dependent variable than the mean reaction time (RT) and the percentage of errors (PE)? Psychologica Belgica, 51(1), 5-13. https://doi.org/10.5334/pb-51-1-5

Burgess, C. i Lund, K. (1997). Modeling parsing constraints with high-dimensional contextspace. Language and Cognitive Processes, 12, 177-210. https://doi.org/10.1080/ 016909697386844

Butterworth, B. (2010). Foundational numerical capacities and the origins of dyscalculia. Trends in Cognitive Sciences, 14(12), 534-541. https://doi.org/10.1016/j.tics.2010. 09.007

Casasanto, D. (2009). Embodiment of abstract concepts: Good and bad in right- and lefthanders. Journal of Experimental Psychology: General, 138(3), 351-367. https://doi.org/10.1037/a0015854

Coello, Y. i Fischer, M. H. (2016). Perceptual and emotional emobdiment. Routledge. https://doi.org/10.4324/9781315751979

Dehaene, S. (2009). Origins of mathematical intuitions: The case of arithmetic. Annals of the New York Academy of Science, 1156, 232-259. https://doi.org/10.1111/j.17496632.2009.04469.x

Dehaene, S. (2011). The number sense (2nd ed). Oxford University Press.

Dehaene, S., Bossini, S. i Giraux, P. (1993). The mental representation of parity and numerical magnitude. Journal of Experimental Psychology: General, 122, 371-396. https://doi.org/10.1037/0096-3445.122.3.371

Dolscheid, S. i Casasanto, D. (2015). Spatial congruity effects reveal metaphorical thinking, not polarity correspondence. Frontiers in Psychology, 6, 1836. https://doi.org/10.3389/ fpsyg.2015.01836

Dove, G. (2016). Three symbol ungrounding problems: Abstract concepts and the future of embodied cognition. Psychonomic Bulletin \& Review, 23, 1109-1121. https://doi.org/ 10.3758/s13423-015-0825-4

Feigenson, L., Dehaene, S. i Spelke, E. (2004). Core systems of number. Trends in Cognitive Sciences, 8(7), 307-314. https://doi.org/10.1016/j.tics.2004.05.002

Fischer, M. H. i Coello, Y. (2016). Conceptual and interactive emobiment. Routledge. https://doi.org/10.4324/9781315751962

Fischer, M. H. i Rottmann, J. (2005). Do negative numbers have a place on the mental number line? Psychology Science, 47, 22-32.

Fischer, M. H. i Shaki, S. (2014). Spatial associations in numerical cognition: From single digits to arithmetic. Quarterly Journal of Experimental Psychology, 67, 1461-1483. https://doi.org/10.1080/17470218.2014.927515

Gevers, W., Santens, S., Dhooge, E., Chen, Q., Van den Bossche, L., Fias, W. i Verguts, T. (2010). Verbal-spatial and visuospatial coding of number-space interactions. Journal of Experimental Psychology: General, 139(1), 180-190. https://doi.org/10.1037/a0017688 
Gevers, W., Verguts, T., Reynvoet, B., Caessens, B. i Fias, W. (2006). Numbers and space: A computational model of the SNARC effect. Journal of Experimental Psychology: Human Perception and Performance, 32(1), 32-44. https://doi.org/10.1037/00961523.32.1.32

Glenberg, A. M. i Robertson, D. A. (1999). Indexical understanding of instructions. Discourse Processes, 28, 1-26. https://doi.org/10.1080/01638539909545067

Gomez, P., Ratcliff, R. i Perea, M. (2007). A model of the go/no-go task. Journal of Experimental Psychology: General, 136(3), 389-413. https://doi.org/10.1037/00963445.136.3.389

Harnad, S. (1990). The symbol grounding problem. Physica D, 42, 335-346. https://doi.org/ 10.1016/0167-2789(90)90087-6

Hines, T. M. (1990). An odd effect: Lengthened reaction times for judgments about odd digits. Memory \& Cognition, 18(1), 40-46. https://doi.org/10.3758/bf03202644

Hines, T. M. (2010). The odd effect and multiple meanings in english of the words "odd" and “even.” Psychological Reports, 107(2), 443-446. https://doi.org/10.2466/04.10.11.22. pr0.107.5.443-446

Hollis, G. (2017). Estimating the average need of semantic knowledge from distributional semantic models. Memory \& Cognition, 45, 1350-1370. https://doi.org/10.3758/ s13421-017-0732-1

Hollis, G. i Westbury, C. (2016). The principals of meaning: Extracting semantic dimensions from co-occurrence models of semantics. Psychonomic Bulletin \& Review, 23, 1744 1756. https://doi.org/10.3758/s13423-016-1053-2

Huber, S., Klein, E., Graf, M., Nuerk, H. C., Moeller, K. i Willmes, K. (2015). Embodied markedness of parity? Examining handedness effects on parity judgments. Psychological Research, 79(6), 963-977. https://doi.org/10.1007/s00426-014-0626-9

Izard, V., Pica, P., Spelke, E. i Dehaene, S. (2008). Exact equality and successor function: Two key concepts on the path towards understanding exact numbers. Philosophical Psychology, 21, 491-505. https://doi.org/10.1080/09515080802285354

Kaschak, M. P. i Glenberg, A. M. (2000). Constructing meaning: The role of affordances and grammatical constructions in sentence comprehension. Journal of Memory and Language , 43, 508-529. https://doi.org/10.1006/jmla.2000.2705

Klauer, K. C. i Musch, J. (2003). Affective priming: Findings and theories. U: J. Musch i K. C. Klauer (Ur.), The psychology of evaluation: Affective processes in cognition and emotion (str. 7-50). Erlbaum.

Kousta, S. T., Vigliocco, G., Vinson, D. P., Andrews, M. i Del Campo, E. (2011). The representation of abstract words: Why emotion matters. Journal of Experimental Psychology: General, 140, 14-34. https://doi.org/10.1037/a0021446 
Lakens, D. (2012). Polarity correspondence in metaphor congruency effects: Structural overlap predicts categorization times for bipolar concepts presented in vertical space. Journal of Experimental Psychology: Learning, Memory, and Cognition, 38(3), 726736. https://doi.org/10.1037/a0024955

Lakoff, G. i Johnson, M. (1980). Metaphors we live by. University of Chicago Press.

Lakoff, G. i Johnson, M. (1999). Philosophy in the flesh: The embodied mind and its challenge to western thought. Basic Books. https://doi.org/10.5860/choice.37-0239

Lakoff, G. i Nunez, R. (2000). Where mathematics comes from: How the embodied mind brings mathematics into being. Basic Books.

Landauer, T. i Dumais, S. (1997). A solutions to Plato's problem: The Latent Semantic Analyis theory of acquistion, induction and representation of knowledge. Psychological Review, 104, 211-240. https://doi.org/10.1037/0033-295X.104.2.211

Leibovich, T. i Ansari, D. (2016). The symbol-grounding problem in numerical cognition: A review of theory, evidence and outstanding questions. Canadian Journal of Experimental Psychology, 70, 12-23. https://doi.org/10.1037/cep0000070

Lenci, A. (2018). Distributional models of word meaning. Annual Review of Linguistics, 4, 151-171. https://doi.org/10.1146/annurev-linguistics-030514-125254

Lyons, I. M. i Ansari, D. (2015). Foundations of children's numerical and mathematical skills: The roles of symbolic and nonsymbolic representations of numerical magnitude. Advances in Child Development and Behavior, 48, 93-116. https://doi.org/10.1016/ bs.acdb.2014.11.003

Lyons, I. M., Ansari, D. i Beilock, S. L. (2012). Symbolic estrangement: Evidence against a strong association between numerical symbols and the quantities they represent. Journal of Experimental Psychology: General, 141, 635-641. https://doi.org/10.1037/a0027248

Martin, A. (2016). GRAPES - Grounding representations in action, perception, and emotion systems: How object properties and categories are represented in the human brain. Psychonomic Bulletin \& Review, 23(4), 979-990. https://doi.org/10.3758/s13423-0150842-3

McNamara, D. S. (2011). Computational methods to extract meaning from text and advance theries of human cognition. Topics in Cognitive Science, 3, 3-17. https://doi.org/10. 1111/j.1756-8765.2010.01117.x

Moyer, R. S. i Landauer, T. K. (1967). Time required for judgments of numerical inequality. Nature, 215, 1519-1520. https://doi.org/10.1038/2151519a0

Moyer, R. S. i Landauer, T. K. (1973). Determinants of reaction time for digit inequality judgments. Bulletin of the Psychonomic Society, 1, 167-168. https://doi.org/10.3758/ bf03334328

Nuerk, H. C., Iversen, W. i Willmes, K. (2004). Notational modulation of the SNARC and the MARC (linguistic markedness of response codes) effect. Quarterly Journal of Experimental Psychology, 57(5), 835-863. https://doi.org/10.1080/ 02724980343000512 
Ostarek, M. i Huettig, F. (2019). Six challenges for embodiment research. Current Directions in Psychological Science, 28, 593-599. https://doi.org/10.1177/0963721419866441

Piazza, M. (2010). Neurocognitive start-up tools for symbolic number representations. Trends in Cognitive Sciences, 14(12), 542-551. https://doi.org/10.1016/j.tics.2010.09.008

Pinhas, M., Shaki, S. i Fischer, M. H. (2014). Heed the signs: Operation signs have spatial associations. Quarterly Journal of Experimental Psychology, 67(8), 1527-1540. https://doi.org/10.1080/17470218.2014.892516

Pinhas, M. i Tzelgov, J. (2012). Expanding on the mental number line: Zero is perceived as the 'smallest'. Journal of Experimental Psychology: Learning, Memory, and Cognition, 38(5), 1187-1205. https://doi.org/10.1037/a0027390

Proctor, R. W. i Cho, Y. S. (2006). Polarity correspondence: A general principle for performance of speeded binary classification tasks. Psychological Bulletin, 132, 416442. https://doi.org/10.1037/0033-2909.132.3.416

Santens, S. i Gevers, W. (2008). The SNARC effect does not imply a mental number line. Cognition, 108(1), 263-270. https://doi.org/10.1016/j.cognition.2008.01.002

Santiago, J. i Lakens, D. (2015). Can conceptual congruency effects between number, time, and space be accounted for by polarity correspondence? Acta Psychologica, 156, 179191. https://doi.org/10.1016/j.actpsy.2014.09.016

Searle, J. R. (1980). Minds, brains, and programs. Behavioral \& Brain Sciences, 3, 417-457. https://doi.org/10.1017/s0140525x00005756

Shapiro, L. A. (2019). Embodied cognition (2nd ed). Routledge. https://doi.org/10.4324/ 9781315180380

Shepard, R. N., Kilpatric, D. W. i Cunningham, J. P. (1975). The internal representation of numbers. Cognitive Psychology, 7(1), 82-138. https://doi.org/10.1016/0010-0285(75) 90006-7

Sherman, M. A. (1973). Bound to be easier? The negative prefix and sentence comprehension. Journal of Verbal Learning and Verbal Behavior, 12, 76-84. https://doi.org/10.1016/ s0022-5371(73)80062-3

Sherman, M. A. (1976). Adjectival negation and the comprehension of multiply negated sentences. Journal of Verbal Learning and Verbal Behavior, 15, 143-157. https://doi.org/10.1016/0022-5371(76)90015-3

Stanfield, R. A. i Zwaan, R. A. (2001). The effect of implied orientation derived from verbal context on picture recognition. Psychological Science, 12, 153-156. https://doi.org/10. $1111 / 1467-9280.00326$

Šetić, M. (2016). Kognitivne i neuronske osnove razumijevanja prirodnih brojeva. Psihologijske teme, 25, 459-478.

Šetić, M. i Domijan, D. (2017). Numerical congruency effect in the sentence-picture verification task. Experimental Psychology, 64, 159-169. https://doi.org/10.1027/16183169/a000358 
Šetić Beg, M., Čičko, J. i Domijan, D. (2021). Symbol grounding of number words in the subitization range. Psychological Research, 85, 720-733. https://doi.org/10.1007/ s00426-019-01265-4

Tzelgov, J., Ganor-Stern, D. i Maymon-Schreiber, K. (2009). The representation of negative numbers: Exploring the effects of mode of processing and notation. Quarterly Journal of Experimental Psychology, 62, 602-624. https://doi.org/10.1080/ 17470210802034751

Varela, F. J., Rosch, E. i Thompson, E. (2017). The embodied mind. Cognitive science and human experience (Revised ed). MIT Press. https://doi.org/10.19079/pr.2017.7.str

Vigliocco, G., Kousta, S. T., Della Rosa, P. A., Vinson, D. P., Tettamanti, M., Devlin, J. T. i Cappa, S. F. (2014). The neural representation of abstract words: The role of emotion. Cerebral Cortex, 24, 1767-1777. https://doi.org/10.1093/cercor/bht025

Vigliocco, G., Kousta, S., Vinson, D., Andrews, M. i Del Campo, E. (2013). The representation of abstract words: What matters? Reply to Paivio's (2013) comment on Kousta et al. (2011). Journal of Experimental Psychology: General, 142, 288-291. https://doi.org/10.1037/a0028749

Warriner, A. B., Kuperman, V. i Brysbaert, M. (2013). Norms of valence, arousal, and dominance for 13,915 English lemmas. Behavior Research Methods, 45(4), 1191-1207. https://doi.org/10.3758/s13428-012-0314-X

Wilkie, J. E. i Bodenhausen, G. V. (2012). Are numbers gendered? Journal of Experimental Psychology: General, 141(2), 206-210. https://doi.org/10.1037/a0024875

Wilkie, J. E. i Bodenhausen, G. V. (2015). The numerology of gender: Gendered perceptions of even and odd numbers. Frontiers in Psychology, 6, 810. https://doi.org/10.3389/ fpsyg.2015.00810

Yee, E., Jones, M. N. i McRae, K. (2018). Semantic memory. U: J. T. Wixted i S. ThompsonSchill (Ur.), The Stevens' handbook of experimental psychology and cognitive neuroscience (4th ed., Vol. 3: Language and Thought, str. 319-356). Wiley. https://doi.org/10.1002/9781119170174.epcn309

Zimmer, K. E. (1964). Affixed negation in English and other languages: An investigation of restricted productivity. Word, 20(2), Supplement (Monograph No. 5).

Zwaan, R. A. (2004). The immersed experiencer: Toward an embodied theory of language comprehension. U: B. H. Ross, (Ur.), The psychology of learning and motivation (str. 35-62). Academic Press. https://doi.org/10.1016/s0079-7421(03)44002-4

Zwaan, R. A. i Pecher, D. (2012). Revisiting mental simulation in language comprehension: Six replication attempts. PloS ONE, 7(12), e51382. https://doi.org/10.1371/journal. pone.0051382

Zwaan, R. A., Stanfield, R. A. i Yaxley, R. H. (2002). Do language comprehenders routinely represent the shapes of objects? Psychological Science, 13, 168-171. https://doi.org/10. $1111 / 1467-9280.00430$ 


\title{
Interaction between Sign and Parity During Processing of Single-Digit Numbers
}

\begin{abstract}
Comprehension of abstract concepts presents an important challenge for a theoretical framework of grounded cognition. One possibility is that abstract concepts are grounded in affective states. In this work, we examined the hypothesis that abstract mathematical concept of parity (even-odd) is associated with positive and negative hedonic tone. In the first experiment, participants performed parity judgment task. Stimuli were whole numbers in the range between -9 to 9 excluding $-5,0$ and 5. Results showed two-way interaction between sign and parity because participants were more efficient with positive than negative even numbers. They were also more efficient with negative than positive odd numbers. In the second experiment, participants were asked to judge whether the presented number is numerically greater or smaller than 5 while they should ignore the sign. The stimuli were the same as in the first experiment. Results showed more complex three-way interaction where participants were more efficient with positive than negative even numbers, as in the first experiment, but this result was restricted to numbers greater than 5 . Results are discussed in the context of the theory of polarity correspondence and the theory of affective grounding.
\end{abstract}

Keywords: numbers, parity, comprehension of abstract concepts, grounded cognition

Primljeno: 9. 1. 2021. 
